\title{
Digital Specific Property of Robots:
}

\author{
A Historical Suggestion from Roman Law
}

\author{
Takashi Izumo*
}

Modern technology calls for the judicial integration of robots into our society as well as their functional integration. Some scholars and industrialists argue that robots might possess their own property and should pay tax; however, it seems premature to grant an electronic personhood to robots at their current technological level. Therefore, another legal institution is needed. With this in mind Pagallo suggests that the concept of 'specific property' (peculium), which was given to Roman slaves, could be applied to highly developed robots. He calls it digital peculium (DP). In this paper, I explain what peculium was in Roman law and compare it with some future regulations for an autonomous taxicab to clarify the similarity and differences between the Roman peculium and DP. Two merits of the introduction of DP are found in my study. First, a robot may have its own DP although it has no personhood. Second, substantive regulations, which were applied to Roman slaves for supporting their masters and creditors, may be reused without destroying the current legal system. In conclusion, it becomes clear that DP is useful as a chrysalis legal institution for supervising robots before they become autonomous in the truest sense of the word.

\section{Introduction}

Modern technology, especially robotics and data science, is aiming at the creation of autonomous entities which can forecast the future and operate by themselves. Industrial robots, home robots, and the artificial intelligence operating behind these devices would replace human workers or at least support them in various fields; therefore, it will be necessary to integrate such entities into our society. Weng et al point out that " $[\mathrm{t}]$ he actual situation involves input and innovation from multiple non-engineering fields that pave the way for harmonious interactions between humans and robots of all shapes, sizes, appearances, and capabilities.'

This integration should cover, also, the application of jurisprudence, above all in the context of justice. The concept of justice is concerned with resource allocation and requires us 'to render to each his/her own' (in Latin: suum cuique tribuere) ${ }^{2}$ therefore, in a future society where humans and robots will live together and share limited resources, this classical definition of justice calls for extension. For example, Bill Gates suggests that either an owner should pay a hefty tax for a robot they have installed or this robot should pay income tax when it replaces a human worker. ${ }^{3}$ From a legal point of view, his suggestion can be interpreted as a method for realising justice: namely, capitalists and their robots should not deprive humans of living resources. However, this admonishment is based on the unproven assumption that robots will be competent enough to possess their own property, otherwise we cannot think of a robot's income or a robot's tax at all. Pagallo argues that this problem would be solved by the legal concept of 'specific property' (in Latin: peculium) that was granted to slaves during the Roman period. ${ }^{4}$

DOI: 10.21552/delphi/2018/1/8

* Assoc. Prof. Dr. jur. Takashi Izumo, Faculty of Law, Asahi University Japan. For correspondence: <izumo_takashi@alice.asahi-u.ac .jp>

1 Yueh-Hsuan Weng, Chien-Hsun Chen and Chuen-Tsai Sun, 'Toward the Human-Robot Co-Existence Society: On Safety Intelligence for Next Generation Robots' (2009) 1 Int J Soc Robot 267,268

2 Max Kaser, Rolf Knütel and Sebastian Lohsse, Römisches Privatrecht (21th edn, C H Beck 2017) 244-245

3 Richard Waters, 'Bill Gates calls for income tax on robots' Financial Times (20 February 2017) <https://www.ft.com/content/d04a89c2 -f6c8-11e6-9516-2d969e0d3b65> accessed 11 September 2018

4 Ugo Pagallo, The Laws of Robots: Crimes, Contracts and Torts (Springer 2013) 103-106 
In this paper, I compare Roman slaves with highly developed robots on the basis of Pagallo's idea and discuss the possibility of 'digital peculium' (hereinafter, this is called 'DP') to identify a method for the judicial integration of this new technology into our society.

\section{The Concept of Peculium in Roman Law}

\section{What is Peculium?}

Watson defines this Latin word in a concise and precise manner as 'the fund that the master allowed a slave to use as if it were the slave's, though in reality it was the master's (since a slave could own nothing) ${ }^{5}$ On the one hand, the granting of peculium to slaves aimed to establish their financial independence. ${ }^{6}$ Julius Paulus, a distinguished jurist of the Roman Empire, permitted slaves free administration of their peculium. ${ }^{7}$ On the other hand, a paterfamilias, ie a man who is the head of a household, could make money through this legal remedy because he maintained ownership of peculium and therefore the more peculium a slave gained through his commercial activities, the larger the estate their master had. ${ }^{8}$ Thus, as Johnston points out, 'the problem here, not least, is that owners ought surely to be free to dispose of their property as they see fit, and to arrange and rearrange their affairs so that property which was once in one peculium is now in another or in none at all'. ${ }^{9}$ Therefore, Roman jurists made rules about the troublesome behaviour of a master who was 'frustrating the trading partner's reasonable expectations as to creditworthiness. ${ }^{10}$

\footnotetext{
5 Alan Watson, Roman Slave Law (The Johns Hopkins University Press 1987) 13

6 Kaser et al (n 2) 103

7 Dig 15.1.48 pr (Dig is an abbreviation for 'Digesta', pr for 'principium')

8 Kaser et al (n 2) 103

9 David Johnston, 'Peculiar Questions' in Paul McKechnie (ed), Thinking Like a Lawyer: Essays on Legal History and General History for John Crook on his Eightieth Birthday (Brill 2002) 6

10 ibid 6

11 Dig 44.7.14, translated by Watson (n 5) 91

12 Watson (n 5) 91

13 ibid 91

14 Kaser et al (n 2) 305
}

\section{Rights and Obligations around Peculium}

\section{a. The Basic Rule}

The legal status of Roman slaves should be understood in two different contexts: namely, contract law and tort law. 'Slaves are bound by their delicts, and if they are manumitted [ie freed from slavery], they remain bound. On contracts, however, they are not bound at civil law, but by natural law their contracts both bind others and they are bound. And so if I pay to a manumitted slave who had lent me money I am released.' ${ }^{11}$ Tort liability is not taken up in this chapter since the focus of this study is on the economic integration of robots.

According to contractual liability in Roman law, a basic rule was that a free person who concluded a contract with another person's slave could sue neither the slave nor this other person in ordinal procedure. ${ }^{12}$ This commercial hardship could be overcome with two legal actions: namely 'action over specific property' (in Latin: actio de peculio) and 'action over something converted to benefits' (in Latin: actio de in rem verso) that were introduced by Roman praetors. 'Here the master was liable up to the value of the peculium at the time of judgement, and also to the extent that his estate had profited. ${ }^{13}$ Kaser et al interpret that the phrase 'up to the value of the peculium' did not mean that a master was obligated to make over the rest of peculium to his slave's creditors, but that he had to pay the debt from his own wallet in the place of the slave. ${ }^{14}$

Imagine the following case. Gaius was the master of Titius, a slave to whom Gaius granted 1,000 sestertius and a small house as peculium. Titius invested 1,000 sestertius in corn dealing and he suffered a serious loss from his own business. He lost all his investment and furthermore owed Sempronius, a corn dealer, 500 sestertius. Sempronius sued Gaius with actio de peculio because he could not sue Titius who was a slave. In this case, Gaius' liability should be limited up to the value of the peculium that was left at the time of judgement. If Titius kept the house which he received from Gaius, then Gaius should pay the debt to Sempronius in place of Titius up to the value of the house. For example, if the house was estimated at 800 sestertius, then Gaius had to pay the debt of 500 sestertius in full; but if it was only worth 300 sestertius, then he was liable only for 300 sestertius. 


\section{b. Special Remedies for Creditors}

\section{i. Fraudulent Disposition through Slaves}

At least three loopholes can be found in the above basic rule. First, a master might reduce the value of peculium fraudulently (eg he could donate it to another free person) and Roman jurists forbade such fraudulent behaviour from masters. Domitius Ulpian (circa 170-223 AD), a prominent Roman jurist, explained what the word 'fraudulently' (in Latin: dolo malo) actually meant. According to his interpretation, this term covered one of the following three cases: (a) a master took back the peculium of his own slave (eg Gaius took back the house from Titius as in the above example), (b) a master allowed his own slave to throw the peculium into disorder, or (c) a master who was notified that he would be sued diverted the peculium to another person. ${ }^{15}$

\section{ii. Unjust Enrichment through Slaves}

Second, it was identified as unfair that a master was not liable for the debts of his slave after his estate was enriched through the use of the peculium (eg slaves shouldered their master's debt or bought daily necessities for their master's family).${ }^{16}$ According to Roman law, masters who were enriched by their slaves' expenses had to pay their slaves' debts up to a ceiling of the value of the enrichment. Even today, this rule is applied in courts (actio de in rem verso).

\section{iii. Instruction from Masters to Slaves}

Third, as Johnston described, the restriction of a master's liability up to the value of the peculium and the actual enrichment was removed when he instructed his slave to trade (eg when appointed as a captain of a ship). ${ }^{17}$ I explain this topic in Section III.2.c in detail.

\section{Application to Robots}

\section{The Concept of Digital Specific Property}

\section{a. Definition of DP}

It is plausible to compare Roman slaves with multifunctional robots for two reasons. First, according to Bodel, Roman slaves flexibly shifted from one job to another; in other words, they were multifunctional entities in Roman society. ${ }^{18}$ Second, a master might increase the value of his slaves by training them, and this training 'was thus an economic as well as a practical investment'. ${ }^{19}$ Likewise, owners of robots can train their robots through machine learning.

On the basis of Watson's definition of peculium (Section II.1), I define the concept of DP as a fund that an owner would permit a robot to use as if it were the robot's, though in reality it was the owner's (since a robot could own nothing). According to Pagallo, this legal institution enables a robot to be an accountable agent without legal personhood. Thus, DP is one of the effective legal systems 'which can properly address the challenges of the agenthood of AI robots in contracts and business law, by making them accountable, without resorting to any form of corporation and hence, any kind of legal personhood of AI robots'. ${ }^{20}$

\section{b. Comparison to Electronic Personhood}

The grant of judicial personhood to robots is another legal means that 'was first coined in 1967 article for LIFE magazine and was more recently introduced in the Draft Report with Recommendations to the Commission on Civil Law Rules on Robotics of the European Parliament's Committee on Legal Affairs' (electronic person, hereinafter, is called ' $\left.E P^{\prime}\right) .{ }^{21}$ One of the most important differences between DP and EP is in this point; that a robot which is registered as an EP possesses its own regular property and the owner no longer has direct ownership (in German: Eigentum, in French: propriété) of the estate of the robot.

However, Pagallo highlights that $[\mathrm{g}]$ ranting robots the status of legal persons just like corporations

\footnotetext{
15 Dig 15.1.21 pr

16 Kaser et al (n 2) 305

17 David Johnston, 'Limiting Liability: Roman Law and the Civil Law Tradition' (1995) 70 Chi-Kent L Rev 1515, 1517-1521

18 John Bodel, 'Slave labour and Roman society' in Keith Bradley and Paul Cartledge (eds), The Cambridge World History of Slavery: Volume I The Ancient Mediterranean World (Cambridge University Press 2011) 331

19 ibid 331

20 Ugo Pagallo, 'Apples, oranges, robots: four misunderstandings in today's debate on the legal status of Al systems', (2018) 376 Phil Trans $R$ Soc A 1, 8-9 <http://dx.doi.org/10.1098/rsta.2018.0168> accessed 20 October 2018

21 Filipe Maia Alexandre, 'The Legal Status of Artificially Intelligent Robots: Personhood, Taxation and Control' (1 June 2017) 16 $<$ https://ssrn.com/abstract=2985466> accessed 20 September 2018
} 
would indeed be a terrible mistake,,22 because there are some problems which would occur from this conception, for example, 'corporations cannot be held criminally responsible in the civil, as opposed to the common, law tradition.'. ${ }^{23}$ This difference would cause defection of EPs from the US to the EU in criminal cases. Furthermore, Solaiman argues that robots, like chimpanzees, are ineligible to be persons as they cannot perform their own duties. ${ }^{24}$

Therefore, as Pagallo recommended, 'in the midterm, we should skip any hypothesis of granting AI robots full legal personhood'. ${ }^{25}$ In the present study, accordingly, the legal status of robots with their DP will be clarified as follows: Robots may possess and administrate their own assets as DP, purely de facto; whereas owners could notify through this instrument how they are willing to invest in these artefacts and trade with others de jure. This de-facto characteristic of DP would make an empirical test possible, as Pagallo citing the example of Tokku in Japan explains, 'most of the issues we are dealing with in this field of technological innovation should in fact be tackled pragmatically.'. ${ }^{26}$ Furthermore, Bryson et al argue that by suspecting the possibility of keeping an appropriate balance between the rights and obligations of AI agents, '[a]utonomous or semi-autonomous robots interacting with humans will inevitably infringe the legal rights of humans' ${ }^{\prime 27}$ in the case of DP, however, since robots operate purely de facto while humans interact with each other de jure, DP would not be a target for this criticism of Bryson et al.

\section{c. An Example: Autonomous Taxicab with DP}

Let us explore this issue further using the concrete example of an autonomous taxicab. Imagine a society where a highly developed taxicab system per-

\footnotetext{
22 Pagallo (n 20) 8

23 ibid 9

24 S M Solaiman, 'Legal personality of robots, corporations, idols and chimpanzees: a quest for legitimacy' (2017) 25 Artif Intell Law 155, 175

25 Pagallo (n 20) 14

26 ibid 13

27 Joanna J Bryson, Mihailis E. Diamantis and Thomas D. Grant, 'Of, for, and by people: the legal lacuna of synthetic persons' (2017) 25 Artif Intell Law 273, 288

28 Maia Alexandre (n 21) 23-24

29 Dig 15.1.15
}

forms autonomously. Each car navigates a city, analysing taxi demand and the other information that may contribute to the revenue of its owner. If a taxicab detects a problem with its functioning (eg extraordinary noise), then it will change direction to a repair shop without human control. Now, an owner (James) has an autonomous taxicab which he calls Nexus. Nexus is usually maintained at Emily's auto repair shop. Here both James and Emily each have a reasonable motive for introducing DP. It is dangerous for James to connect Nexus' debts with his bank account directly (eg Nexus could make a contract with Emily for repairing at high prices even though it is better for James to scrap this taxicab in the event of a serious breakdown or time-related deterioration). This situation is risky for Emily too because it is difficult to know how much James is willing to pay and she cannot sue Nexus directly on the ground because the taxicab does not have personhood.

DP may offer a solution, if Nexus has DP and Emily can inquire about it with a special app. If the app indicates that Nexus' DP will not cover payment, or even if it is enough, but the repair cost is very expensive, then Emily should contact James before performing the repair, or risk that this taxicab might become insolvent before the DP payment due date. If she sues James for payment in the place of Nexus, then he is liable but only up to the value of the DP that was left on the due date. In other words, DP is a so-called yardstick which humans could use to measure the appropriateness of a contract.

Someone could question why James' estate is not strictly separated from Nexus' DP; however, this continuity of ownership between the owner's assets and the DP could be of merit. For example, Maia Alexandre is concerned about tax avoidance via the assets of artificially intelligent agents and calls on regulators to prevent such abuse. ${ }^{28}$ In the case of DP, the risk of tax avoidance would be relatively low because the owner of a robot is the owner of its DP and hence he should pay tax imposed on the DP by himself/herself.

\section{d. Multiple Legal Relations}

Perhaps the Roman concept of peculium could be applied to multiple legal relations. For example, if two masters (eg Gaius and Titius) share one slave, Stichus, then Gaius and Titius should obey the following two rules: ${ }^{29}(1)$ if it is clear which parts of 
Stichus' peculium belong to Gaius and which to Titius (eg Stichus' house was given as peculium by Gaius but his horse by Titius independently), then each master should be liable only up to his own share of the peculium; however, (2) if not only the slave but also his peculium was common to Gaius and Titius, then they should be joint debtors of the entire value of peculium. Likewise, these two rules seem applicable to DP: the co-owners of a robot should be joint debtors for their robot's activities when it is unclear which parts of DP belong to whom. Similar rules can be found even today, especially regarding the co-ownership of real estate (eg in Germany: $\ 134$ Abs 1 Satz 4 BauGB).

\section{Legal Measures against Responsibility Avoidance}

\section{a. Fraudulent Disposition and Unfair Payments through Robots}

Stability and predictability are the two bases of the modern legal system. It is destructive that a classical rule will be abolished just because a new concept has been introduced into an old system. Therefore, I argue that a new legal system should include some regulations about highly developed robots which should take over the current legal concepts as much as possible. For example, the precedents and laws about fraudulent disposition should be applicable to owners whose robots with DP become insolvent de facto. Today, also unfair preference, ie preferential payments shortly before becoming bankrupt, is forbid-

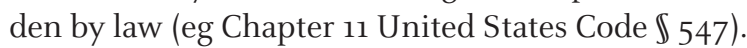

If the complexity of a free market calls for an efficient digital system to supervise trading robots, then I suggest that their contracts could be controlled in the form of smart contracts. As Swan explains, 'the blockchain could be one potential path to artificial intelligence (AI) in the sense that smart-contract platforms are being designed to run at graduated stages of increasing automation, autonomy, and complexity. ${ }^{30}$ Thus DP as a blockchain wallet could be an extensive application of smart contracts, separating DP from the owner's wallet purely de facto. Owners of robots would be able to calculate their exact investment in their artefacts through this virtual wallet without violating each other's financial privacy. This technology could contribute to the ability to trace en- tire series of trading transactions and check whether or not a robot has already become insolvent. An insolvent robot would be banned from the market as soon as the blockchain system identifies its insolvency or breakdown. As Pagallo observes, a master could prohibit other free persons from dealing with a certain slave through public notification. ${ }^{31}$ In comparing Roman and US slavery, Scheidel similarly mentions that a tracing system is important, especially for future generations to be able to inquire into the details of past trades. ${ }^{32}$

Evidently, there are some technical challenges related to blockchain, including data bloats, which increase the time required to download information to as long as one day. ${ }^{33}$ It is reasonable to predict that the total sum of data on the smart contracts concluded by AI agents will be so enormous that the system will eventually become incapable of functioning; therefore, the successful operation of a smart contract system with DP would require restrictions on the kinds of trade to which blockchain should be applied (eg land transactions).

\section{b. Unjust Enrichment through Robots}

If a robot used its own DP for the owner or the owner's family, then this enrichment should be taken into account when locating responsibility, as in the Roman case of actio de in rem verso. For example, if Nexus paid James' debt of €10,000 and became insolvent, then Emily can charge James up to the limit of the value of the DP plus $€ 10,000$ that he profited by Nexus's payment.

Abundant precedents concerning so-called unjust enrichment contribute an answer to the question of what kind of profit should be returned to creditors in such a case. Leow et al point out in the context of the Singapore legal system that ' $[t]$ he current shape and continued development of the law of unjust enrichment is the product of an ongoing conversation between academic commentators and courts' (italics

\footnotetext{
30 Melanie Swan, Blockchain: Blueprint for a New Economy (O’Reilly 2015) 26

31 Pagallo (n 4) 104

32 Walter Scheidel, 'The Roman slave supply' in Keith Bradley and Paul Cartledge (eds), The Cambridge World History of Slavery: Volume I The Ancient Mediterranean World (Cambridge University Press 2011) 287

33 Swan (n 30) 82
} 
mine),${ }^{34}$ and the problem of the unjust enrichment performed through autonomous robots probably will become a future topic in this field.

\section{c. Instruction from Owners to Robots}

In Roman law, if a master authorised his slave to make a certain contract or appointed the slave as a manager of a business, then he had to pay the debts that derived from the authorisation or appointment in full, and Roman jurists granted creditors 'action over something ordered' (in Latin: actio quod iussu) in the former case and 'action over management' (in Latin: actio institoria) in the latter. ${ }^{35}$ In this paper, I refrain from discussing the latter action because no robot has the ability to be a manager at the moment.

This persuasive Roman rule is applicable to robots at least in the context of specific instruction, and therefore an owner must be liable for problems caused by their programming or data installation when they intended their robot to take a certain action. For example, in the above case of the autonomous taxicab, if James gave an order to Nexus to be repaired by Emily, then he should be liable for the repair cost in full. However, contrary to the unmistakable instruction, it seems difficult to establish a simple rule for an ambiguous one (eg James said: 'Nexus, you should be repaired by Emily if necessary'). I argue that safety and stability are the minimum rules determining this matter. It is unacceptable that an owner programmes his/her autonomous

34 Rachel Leow and Timothy Liau, 'Unjust enrichment and restitution in Singapore: Where now and where next?' (2013) Sing J Legal Stud 331, 332

35 Kaser et al (n 2) 306 cab to reduce maintenance costs and to prioritise making money, because such frugality could lead to a traffic accident.

\section{Conclusion}

DP, an imitation of the concept of peculium granted to Roman slaves, is not only possible but also useful for determining the location of property and the identity of the entity responsible for it. By granting DP, the owner of a robot can declare de jure how much he/she thereby invests in it and can inform creditors who deal with this robot about its financial affairs, while the robot itself interacts with other robots or humans purely de facto, ie this artefact does not call for its own rights or obligations. DP, like the Roman peculium, would be in danger of abuse (eg fraudulent disposition); however, measures developed by Roman and modern lawyers can be taken, despite its continuous development today. By introducing blockchain smart contracts, the legal function of DP could be enhanced, although there are some limitations, because creditors might need to trace the details of trading processes. An alternative legal remedy, ie the granting of a judicial personhood to robots, is premature, especially because legal systems pertaining to judicial personhood are different from one state to another and it is difficult to unify them. In the meantime, owners should supervise their robots appropriately and take responsibility for them now as the de-facto agenthood of robots is improved day by day. The introduction of DP should be understood as a chrysalis stage in the development of the autonomy of robots in the true sense of the word. 